\title{
The Contribution of Assertive Technique Behavioral Counseling to Minimize the Juvenile Delinquency Behavior
}

\author{
Zadrian $\operatorname{Ardi}^{1}, \&$ Mey $\operatorname{Sisin}^{2 *}$ \\ ${ }^{1,2}$ Faculty of Education, Universitas Negeri Padang \\ ${ }^{*}$ Corresponding Author
}

\begin{abstract}
The purpose of this study was to determine the effectiveness of behavioral counseling using assertive technique to minimize the juvenile delinquency of students. This research is an experimental research design. The study population was the eighth grade students in South Solok West Sumatra consist of 82 students using Random Sampling. Data collection methods that used in this study were a questionnaire method. Data were analyzed by t-test with SPSS 20.0 for Windows. The results showed that there are significant differences between the groups which have deviant behavior who take behavioral counseling session with a group of students who do not follow the behavioral counseling session. It could be seen from a group of students who take behavioral counseling session (133.17) compare with a group of students who do not follow behavioral counseling session (85.32), and from the analysis of $t$ with $d f=$ 82 and $1 \%$ significance level $(t=0.053, p<0.01)$. So the application of behavioral counseling Training assertive techniques to minimize misbehavior is effective to reduce the juvenile delinquency of students.
\end{abstract}

Keyword: behavioral counseling, assertive training, juvenile delinquency

Copyright (C) 2016 IICET (Indonesia) - All Rights Reserved

Indonesian Institute for Counseling, Education and Therapy (IICET)

\section{INTRODUCTION}

Education is a process that seeks to cultivate students to be the subject of human resources (HR) quality for human survival sustainability (Ardi, Viola, \& Sukmawati, 2018; Syahniar, Ifdil, Afdal, \& Ardi, 2018). Through education, people will be able to make sense of life and compete in the era of globalization. According to the Indonesian National Education System states that education is a conscious and deliberate effort to create an atmosphere of learning and the learning process so that students are actively developing their own potentials and have religious spiritual activities, self-control, personality, intelligence, character and the skills required himself, society, nation and state (Abbott, 2017; Estriyanto, Kersten, Pardjono, \& Sofyan, 2017).

Teachers play an important role in the educational process, especially in schools, because in terms of education, the teacher has an important role in mental development of students. To achieve this, the government today has made various efforts to improve the skills one teacher. Also supported by the

*Corresponding Author E-mail : meysisin5@gmail.com 
development of the curriculum along with the provision of facilities and infrastructure. It is intended to improve the quality of human resources so that they can live independent, productive and responsible both to themselves, their families and communities. In the implementation of these activities, it is not always proceed smoothly due to many factors (Organization, 2016; Sweeney, Danaher, \& McColl-Kennedy, 2015; Valverde, Hernández-Pérez, \& Paredes-López, 2015; Western, 2018).

For the success of education in schools, many factors could affect, such as teacher, environment, peers also very influential (Ardi \& Maizura, 2018). Although schools have set up professional educators, facilities and infrastructure, schools will not produce quality graduates if factors of the students psychological do not support. Especially in the learning process, state of being of the individual/student the physical and the psychological well should also be noted. One form of irregularities committed among students is increasing deviant behavior that violates school discipline (Gummadam, Pittman, \& Ioffe, 2016; Jang, Kim, \& Reeve, 2016; Tandoc, Ferrucci, \& Duffy, 2015; Tennant et al., 2015).

Deviant behavior is a problem that needs to be addressed and require the guidance of teachers and counselors (Osgood, Wilson, O’malley, Bachman, \& Johnston, 2017; Patterson, DeBaryshe, \& Ramsey, 2017). Deviant behavior in schools with less formation ability of self-discipline, controlling behavior and requires the guidance of teachers are, among others, delays, ditching, against teachers, fights, cheating and so on (Bishop et al., 2018; Conrad, 2017; Moffitt, 2017). Deviant behavior that commonly occurs in adolescents is also often said to be juvenile delinquency (Hawkins \& Weis, 2017; Hoffmann \& Dufur, 2018; Plantz \& Garbarino, 2017; Simmons, Steinberg, Frick, \& Cauffman, 2018; Sykes \& Matza, 2017). Students who violate the discipline cannot be responsible for the study, this will damage potential, talents, abilities, ideals, and their future. So that the behavior of students who violate disciplines will hinder the achievement of national education goals, which is to the intellectual life of the nation and developing the whole person, the man whose faith and fear of God Almighty and noble character, has the knowledge and skill, physical and spiritual health, personality stable and independent, as well as a sense of responsibility and national community (Plantz \& Garbarino, 2017; Simmons et al., 2018; Sykes \& Matza, 2017).

In addition to inhibiting the purpose of education, juvenile delinquency is also a behavior that violates social norms, for students whose behavior deviates will tend to do things or acts that negative that would be detrimental to the surrounding community and is a behavior that violates social norms as a result of the process of conditioning a bad neighborhood (Daharnis \& Ardi, 2016). Usually students are easily affected solicitation of friends. Among teens, especially high school students, had many friends is a fun thing (Hawkins \& Weis, 2017; Hoffmann \& Dufur, 2018; Osgood et al., 2017). Having a lot of friends will be a pride for a student. But not all friends have a positive influence. Some friends certainly there are also a negative influence. The influence of friends in shaping the character is quite large. Teens tend to be more frequent activities or communicating with friends of her parents (Plantz \& Garbarino, 2017; Simmons et al., 2018; Sykes \& Matza, 2017). If, students often perform activities or communicating with friends who had a negative impact for example by a friend who would take him truant at school hours, and affect other students with the words "What are you doing in school who also will later you change, you want to be the Regent are still many who fight so candidates, here do not go to school". Indirectly, these students will be affected by his friends who will automatically skipped school the student is already have deviant behavior, and violating school rules (Ardi, Ibrahim, \& Said, 2012; Ardi, Yendi, \& Ifdil, 2013; Ifdil \& Ardi, 2013; Yanti, Erlamsyah, Zikra, \& Ardi, 2013).

If this trend continues, they will fail in the study because they can live class, or it may also drop out of school. For anticipating that possibility, then the role of the school in essentially no far i.e. different from the role of family as a reference and point of service and guidance to learners at school (Ardi, Putra, \& Ifdil, 2017). One component of school plays an important role in this regard is counseling. Counseling is one of the means of assistance in the form of services to help individuals (Students) to solve the problems or obstacles they face and help students to develop the potential of students (Ardi, 2014; Ardi \& Yendi, 2013; Restu, 
Yusri, \& Ardi, 2013; Yendi, Ardi, \& Ifdil, 2014). Through individual counseling process led to direct his own life through a variety of considerations, making a plan, making wise decisions and take responsibility for the decisions taken. Students are helped to develop the concept itself positive so that eventually they can develop in a positive way, so that eventually they can develop positive anyway.

Seeing the problems mentioned above, guidance and counseling in schools should be proactive in addressing this issue (Ardi \& Erlamsyah, 2017). In the implementation of counseling, there are some counseling models, among them: the humanistic counseling model, the model of behavioral counseling, counseling trait and factor models, models of reality counseling, counseling model gestalt, psychoanalytic counseling model, a model client counseling centers and existential humanistic counseling model. If viewed from the problem of deviant behavior counseling students one of the models from which applied is a model of behavioral counseling.

According to the theory of behavioral counseling by Krumboltz states that man is shaped and conditioned by the social, cultural, and assumes that the behavior is the result of learning and conditioning. Behavioral counseling theories and techniques based on the principles of learning theory. Normal behavior learned from strengthening and impersonation (Daharnis, Ardi, \& Ifdil, 2018). Abnormal behavior is a result of learning the "wrong". The purpose of this counseling is the individual would be able to remove the patterns of negative behavior, helping clients learn constructive behavior and changing individual behavior into a more positive direction (Allen \& Bradley, 2015; de Vries, Hoeve, Assink, Stams, \& Asscher, 2015).

Behavioral counseling states that human behavior can be altered or manipulated, by training his behavior. Manipulation that is by providing exercises that bad behavior bias minimized and gradually becomes lost. In counseling behavioral, there are several technique that is Desensitization systematic, impulsive and flooding therapy, operant conditioning, aversion therapy (Dehnavi \& Ebrahimi, 2016; Puri \& Luqman, 2015; Rani, Chandran, \& Singal, 2016), assertiveness training (Ardi \& Yendi, 2017). Seeing the problems above, guidance and counseling to provide an alternative solution to the problems. One of the ways used in solving the problem of juvenile delinquency is by assertive training techniques. The foundation of this training assertive use of the technique is a strategy counseling in behavioral approach used to develop assertive behavior on the client (Ardi, 2017). The basic assumptions of assertive training is that every person has the right to express his feelings, opinions, what is believed to be as well as his attitude toward others with permanent respect for and respecting the rights of the person.

Based on these opinions above, assertive training is one strategy relief behavior therapy that be used or recommended to reduce and eliminate the anxiety disorders as well as improving the interpersonal skills of individuals that aims to develop the client's expression of positive feelings (Daharnis \& Ardi, 2018). Based on these descriptions, the juvenile delinquency could be minimized by providing assertive training in behavioral counseling techniques (Boket, Bahrami, Kolyaie, \& Hosseini, 2016; Parray \& Kumar, 2017; Puri \& Luqman, 2015). Counseling involves helping people through the process of interaction of a personal nature between the counselor and the counselee, counselee able to understand themselves and their surroundings, able to make decisions and set goals based on common values that so that counselees feel happy and effective behavior (Boket et al., 2016; Keliat, Tololiu, Daulima, \& Erawati, 2015; Schry \& White, 2016).

Counseling is a process of assistance provided to individuals in solving the problems of life with interviews and in a manner appropriate to the circumstances faced by individuals to achieve their welfare (Dantes, Susanta, \& Suarni, 2017; Grinstein \& Kronrod, 2016; Schry \& White, 2016). Meanwhile, according to ASCA (American School Counselor Association) argues that the relationship face to face in counseling is confidential, full acceptance and granting chance of counselor to the client (Ardi \& Sukmawati, 2017). Counselors use the knowledge and skills to help clients cope with the problem. Based on some of the terms mentioned above it can be concluded counseling is the process of assistance by the counselee continuity that aimed independent counselees (Daharnis \& Ardi, 2017). Counseling is a relationship between the helper 
(person who provides assistance) who have been trained by people who seek help (those who receive assistance) based on the skills helper and the atmosphere that was created to help, learn to build relationships with themselves and others in a productive manner (growth-producing). By understanding a few opinions on the above, it can be concluded that counseling is the process of giving assistance undertaken in direct face to face relationship (face to face relationship) by an expert referred to a counselor who need the help that called counselees/client (Chen \& Giblin, 2017; Grinstein \& Kronrod, 2016; Speed, Goldstein, \& Goldfried, 2018).

Understanding the behavioral counseling based on the theory of learning, behavior modification and therapy behavior are approaches to counseling and psychotherapy to deal with changes in behavior. Behavior therapy is the application of a variety of techniques and procedures that are rooted in the various theories of learning (Mazur, 2016). It includes the systematic application of principles learned at changing behavior towards ways that are more adaptive. In accordance with the above statement, then behavior can be changed or developed from a low social behavior into a higher social behavior (Allen \& Bradley, 2015; de Vries et al., 2015; Sue, Sue, Sue, \& Sue, 2015).

Counseling strategies in behavior approach used to develop assertive behavior on the client. Assertive training is given to individuals who disturbed anxiety, unable to defend their rights, too weak, let others push him, not be able to express anger properly and quickly offended. Assertively constitute an ability to communicate what they want, feel and think about other people while maintaining and respecting the rights and feelings of others (Boket et al., 2016; Keliat et al., 2015; Parray \& Kumar, 2017). The basic assumption of assertiveness training is that every person has the right to her feelings, opinions, what is believed and attitudes towards others with respect and to respect the rights of the person. Then assertive training is one of the strategies the help of behavioral therapy approaches were used or recommended to reduce and eliminate the anxiety disorders as well as increase. Assertiveness training can be interpreted also as a technique in behavioral disorder treatments where the client is instructed, directed, trained, and supported to be assertive in the face of uncomfortable situations or less favorable to him (Dantes et al., 2017; Grinstein \& Kronrod, 2016; Rani et al., 2016; Schry \& White, 2016). Assertiveness training is a summary of the systematic of skills, rules, concepts or attitudes that can develop and train the individual's ability to deliver frank thoughts, feelings, desires and needs with confidence so that they can relate well with their social environment. The core of assertiveness training is an investment trust that assertiveness can be trained and developed, choosing the right words for the purpose they want, mutual support, turning for every participant of the trainers and participants (Dehnavi \& Ebrahimi, 2016; Parray \& Kumar, 2017; Puri \& Luqman, 2015).

Deviant behaviors are all actions that deviate from the norms prevailing in the social system and leads to efforts of those authorities are in the system to correct deviant behavior. In the science of Sociology their theory of Differential Association or a different association stated. He found irregularities stem from a different association. Deviations learned through a process of cultural experts. Through this process, a person learns a deviant culture, as example is the juvenile delinquency (Puri \& Luqman, 2015; Rani et al., 2016). For example, people refer to as thieves, swindlers, drunks, slut, etc., so that the offender compelled to deviate secondary (advanced stage), by reason of abysmal. Deviation behavior it is an adaptation to a particular situation. Merton identified five types of adaptation measures, which four of them are deviant behavior (Dantes et al., 2017; Keliat et al., 2015; Schry \& White, 2016), namely: 1) conformities, the following behavior of interest and follow the prescribed manner the community to achieve these objectives, 2) Innovation, that behavior to follow the specified destination community, but in a manner prohibited society, 3) Ritualism or competition themselves, the attitude of a person who has left a cultural destination, but still in the ways outlined society. 4) Competition themselves, which rejected the approved objectives and ways of reaching that goal, 5) Rebellion or insurrection, the withdrawal of goals and ways conventional accompanied by efforts to institutionalize goals and new ways.

Deviant behavior covers several aspects, namely: aspects of physical and symbolic aspect, has the form of passive and aggressive, symptom-shaped neurotic and psychosomatic (Boket et al., 2016; Keliat et al., 
2015; Parray \& Kumar, 2017; Schry \& White, 2016), which is included in the aspect of the outward is a deviation in the form of verbal namely in form of harsh words, profanity, and so forth, and nonverbal real deviations visible.

\section{METHODS}

This research is experimental research that included the type of quasi-experimental. The sample of this study consist of 82 students. The data collected in this study using questionnaire about juvenile delinquency of students in school. The research data were analyzed using t-test analysis. This study uses two sample groups, which is experimental group and control group. Student t-tests were conducted to see the contribution of behavioral counseling to juvenile delinquency conditions.

\section{RESULT AND DISCUSSIONS}

After dividing the two main groups in the form of control and experimental groups, the indicated subjects had a tendency to be teenagers given different treatment according to their group. Assertive techniques in behavioral counseling approaches are given to the experimental group, while conventional approaches are given to the control group.

Table 1 Juvenile Delinquency Trends after being given assertive techniques in behavioral counseling in the experimental group

$(n=41)$

\begin{tabular}{cccc}
\hline Interval & Categories & f & $\%$ \\
\hline $\mathbf{1 3 1}-\boldsymbol{x}-\mathbf{1 5 0}$ & Very high & 0 & 0 \\
$\mathbf{1 1 1}-\boldsymbol{x}-\mathbf{1 3 0}$ & High & 0 & 0 \\
$\mathbf{7 1}-\boldsymbol{x}-\mathbf{1 1 0}$ & Moderate & 0 & 0 \\
$\mathbf{5 1}-\boldsymbol{x}-\mathbf{7 0}$ & Low & 12 & 29 \\
$\mathbf{3 0}-\boldsymbol{x}-\mathbf{5 0}$ & Very low & 29 & 71 \\
\hline
\end{tabular}

The implementation of assertive techniques in behavioral counseling is given three sessions. The impact of changes in juvenile delinquency trends was then re-measured using a juvenile delinquency questionnaire. Achievement of juvenile delinquency trends in the experimental group after being treated as described in Table 1. The tendency to do juvenile delinquency in general can be derived by the application of assertive techniques in behavioral counseling. This is indicated by the achievement of $71 \%$ of respondents who were in the trend of juvenile delinquency at the lowest level, and the other $29 \%$ were at a low level. This can be interpreted as a general decline in juvenile delinquency after treatment

Table 2 Juvenile Delinquency Trends after being given assertive techniques in behavioral counseling in the control group

$(n=41)$

\begin{tabular}{cccc}
\hline Interval & Categories & f & \% \\
\hline $\mathbf{1 3 1}-\boldsymbol{x}-\mathbf{1 5 0}$ & Very high & 0 & 0 \\
$\mathbf{1 1 1}-\boldsymbol{x}-\mathbf{1 3 0}$ & High & 3 & 7.317 \\
$\mathbf{7 1}-\boldsymbol{x}-\mathbf{1 1 0}$ & moderate & 33 & 80.488 \\
$\mathbf{5 1}-\boldsymbol{x}-\mathbf{7 0}$ & Low & 5 & 12.195 \\
$\mathbf{3 0}-\boldsymbol{x}-\mathbf{5 0}$ & Very low & 0 & 0,00 \\
\hline
\end{tabular}


Less effective results were obtained by 41 respondents in the control group. This is indicated by the presence of 3 respondents $(7.3 \%)$ who have a high tendency of juvenile delinquency. In addition, there are still $80 \%$ of respondents in the control group who have juvenile delinquency at a moderate level.

A deeper analysis is done by comparing the results of the two groups of data. Based on the data normality test by applying the Kolmogorov-Smirnov technique, it was found that the data distribution in the experimental and control groups was in the normal data category. This is based on data exposure that the significance of the distribution in the experimental group was at 0.11 and the control group was at 0.20 , so there was no difference between the data tested and the normal data distribution, in other words the distribution of data in both groups was in the normal category.

Table 3 The Test of Normality of Experiment Group

\begin{tabular}{llccccc}
\hline & \multicolumn{3}{c}{ Kolmogorov-Smirnov } & \multicolumn{3}{c}{ Shapiro-Wilk } \\
\hline & Stat. & df & Sig. & Stat. & df & Sig. \\
Experiment Group & .125 & 41 & .110 & .953 & 41 & .091 \\
\hline
\end{tabular}

In addition, a homogeneity test is conducted to test whether there is a similarity index of variance from the two data groups. In addition, this test is used to ensure that data groups do come from the same sample. Based on the explanation in Table 5, it is known that the significance index is above 0.05 , so it can be said that both data groups have the same variance, so that they meet the requirements for different tests through a t-test.

Table 4 The Test of Normality of Control Group

\begin{tabular}{llccccc}
\hline & \multicolumn{3}{c}{ Kolmogorov-Smirnov } & \multicolumn{3}{c}{ Shapiro-Wilk } \\
\hline & Stat. & df & Sig. & Stat. & df & Sig. \\
Control Group & .105 & 41 & .200 & .941 & 41 & .033 \\
\hline
\end{tabular}

Table 5 The Test of Variable Homogeneity

\begin{tabular}{llcccc}
\hline & & $\begin{array}{l}\text { Levene } \\
\text { Statistic }\end{array}$ & df1 & df2 & Sig. \\
\hline $\begin{array}{l}\text { Jun. } \\
\text { Delinq. }\end{array}$ & Based on Mean & 3,861 & 1 & 80 & .053 \\
& Based on Median & 3,488 & 1 & 80 & .065 \\
& $\begin{array}{l}\text { Based on median and } \\
\text { with adjusted df } \\
\text { Based on the trimmed } \\
\text { mean }\end{array}$ & 3,488 & 1 & 63 & .066 \\
& 3,667 & 1 & 80 & .059 \\
\hline
\end{tabular}


The research findings presented in Table 6 indicate that there are significant differences between the control and experimental groups with an $\mathrm{F}$ value of 3,861 and a significance of 0,000 . The achievement of the reduction in juvenile delinquency tendency was in the experimental group, namely more than half of the respondents in this group had very low juvenile delinquency after being given treatment through assertive techniques on behavioral counseling.

Table 6 Independent Sample t-test of Experiment and Control Group

\begin{tabular}{|c|c|c|c|c|c|c|c|c|c|}
\hline & \multicolumn{4}{|c|}{$\begin{array}{l}\text { Levene's Test for Equality of } \\
\text { Variances }\end{array}$} & \multicolumn{3}{|c|}{ t-test for Equality of Means } & \multirow{2}{*}{\multicolumn{2}{|c|}{$\begin{array}{l}95 \% \text { Confidence } \\
\text { Interval of the } \\
\text { Difference }\end{array}$}} \\
\hline & \multirow[t]{2}{*}{$\mathrm{F}$} & \multirow[t]{2}{*}{ Sig. } & \multirow[t]{2}{*}{$\mathrm{t}$} & \multirow[t]{2}{*}{$\mathrm{df}$} & \multirow[t]{2}{*}{$\begin{array}{c}\text { Sig. } \\
\text { (2tailed) }\end{array}$} & \multirow[t]{2}{*}{$\begin{array}{c}\text { mean } \\
\text { Difference }\end{array}$} & \multirow[t]{2}{*}{$\begin{array}{l}\text { Std. error } \\
\text { Difference }\end{array}$} & & \\
\hline & & & & & & & & Lower & Upper \\
\hline Equal variances assumed & 3,861 & .053 & 22.229 & 80 & .000 & 47.85366 & 2.15280 & 43.56944 & 52.13787 \\
\hline Equal variances not assumed & & & 22.229 & 65 & .000 & & 2.15280 & 43.55489 & 52.15242 \\
\hline
\end{tabular}

The decreasing level of juvenile delinquency after being given treatment in the form of assertive training in behavioral counseling indicates that the behavioral approach can effectively be applied to various misbehavior of students. The tendency of juvenile delinquency that is common in schools can be suppressed by the application of this technique. It is also emphasized on the technique to dare to reject various invitations by peers to carry out various activities that lead to maladaptive behavior.

Training students to be able to avoid adolescent delinquency firmly to say "no" to assertive training is believed to be an effective approach. This method can be used by counselors in schools in handling and preventing the emergence of juvenile delinquency which in essence will harm the students themselves. In addition, alleviating juvenile delinquency conditions can be simultaneously carried out through this technique, so that misguided behaviors that have been applied by students in their daily lives can be suppressed at very low levels.

\section{CONCLUSIONS}

Behavioral counseling approach is one of the effective steps in changing and manipulating the wrong behavior experienced by students, where the behavior often appears in the form of juvenile delinquency. Research findings show that by applying one of the behavioral counseling techniques, namely assertive techniques / exercises, the tendency of juvenile delinquency can be effectively reduced at a low level.

This is a significant manifestation of assertive training, where students are able to say "no" to every invitation to do juvenile delinquency. This condition can suppress various potential juvenile delinquency that might emerge in the future. Statistically, conventional approaches are also less effective in suppressing juvenile delinquency, in this case the process of counseling services. So, with the application of one of the behavioral counseling techniques, the likelihood and tendency of juvenile delinquency can be suppressed so that the potential of students can be developed in a more positive direction.

In addition, further research is needed regarding the possibility of various other approaches that are more effective in suppressing juvenile delinquency, especially with regard to their potential. The scope of the sample in research on juvenile delinquency also needs to be enlarged so that the results obtained can be applied in various types of demographics. 


\section{REFERENCES}

Abbott, A. (2017). Indonesian Identity and Cultural Values. In Educational Sovereignty and Transnational Exchanges in Post-Secondary Indonesian Education (pp. 135-161). Springer.

Allen, K. R., \& Bradley, L. (2015). Career Counseling With Juvenile Offenders: Effects on Self-Efficacy and Career Maturity. Journal of Addictions \& Offender Counseling, 36(1), $28-42$.

Ardi, Z. (2014). Cita-cita Perkerjaan dan Pilihan Peminatan Siswa Sekolah Menengah Atas Negeri di Sumatera Barat.

Ardi, Z. (2017). Unsuitable Majoring: Does the Reorientation Would Help the Student for Revitalize Learning Activities? In Proceedings of the 9th International Conference for Science Educators and Teachers (ICSET 2017). Paris, France: Atlantis Press. https://doi.org/10.2991/icset-17.2017.69

Ardi, Z., \& Erlamsyah, E. (2017). Peningkatan Kualitas Penulisan Artikel Ilmiah bagi Kepala Sekolah. Jurnal Aplikasi IPTEK Indonesia, 1(1), 25-34.

Ardi, Z., \& Maizura, N. (2018). The Psychological Analysis of Divorce at Early Marriage. International Journal of Research in Counseling and Education, 1(3), 27-32.

Ardi, Z., \& Sukmawati, I. (2017). Social Media and the Quality of Subjective Well-Being; Counseling Perspective in Digital Era. Open Science Framework. October.

Ardi, Z., \& Yendi, F. M. (2013). Konseling Online: Sebuah Pendekatan Teknologi Dalam Pelayanan Konseling. Jurnal Konseling Dan Pendidikan, 1(1), 1-5.

Ardi, Z., \& Yendi, F. M. (2017). Students Attitude Towards LGBTQ; the Future Counselor Challenges. Jurnal Konseling Dan Pendidikan, 5(2), 74-79. Retrieved from http://jurnal.konselingindonesia.com/index.php/jkp/article/viewFile/181/161

Ardi, Z., Ibrahim, Y., \& Said, A. (2012). Capaian Tugas Perkembangan Sosial Siswa dengan Kelompok Teman Sebaya dan Implikasinya terhadap Program Pelayanan Bimbingan dan Konseling. Konselor, 1(2).

Ardi, Z., Putra, M. R. M., \& Ifdil, I. (2017). Ethics And Legal Issues In Online Counseling Services: Counseling Principles Analysis. Jurnal Psikologi Pendidikan Dan Konseling: Jurnal Kajian Psikologi Pendidikan Dan Bimbingan Konseling, 15-22.

Ardi, Z., Viola, K., \& Sukmawati, I. (2018). An Analysis of Internet Abuses Impact on Children's Moral Development. JPPI (Jurnal Penelitian Pendidikan Indonesia), 4(1), 44-50.

Ardi, Z., Yendi, F. M., \& Ifdil, I. (2013). Konseling Online: Sebuah Pendekatan Teknologi Dalam Pelayanan Konseling. Jurnal Konseling Dan Pendidikan, 1(1), 1-5.

Bishop, S. A., Okagbue, H. I., Oludayo, O. A., Agboola, O. O., Agarana, M. C., \& Adamu, M. O. (2018). Survey dataset on the types, prevalence and causes of deviant behavior among secondary school adolescents in some selected schools in Benin City, Edo State, Nigeria. Data in Brief. 
Boket, E. G., Bahrami, M., Kolyaie, L., \& Hosseini, S. A. (2016). The effect of assertiveness skills training on reduction of verbal victimization of high school students. International Journal of Humanities and Cultural Studies (IJHCS) ISSN 2356-5926, 3(2).

Chen, M., \& Giblin, N. J. (2017). Individual Counseling and Therapy: Skills and Techniques. Routledge.

Conrad, P. (2017). Identifying Behavior as Deviant and Defining Deviance as a Medical Problem: Audience Reactions to Children's Behavior. In Identifying Hyperactive Children (pp. 3350). Routledge.

Daharnis, D., \& Ardi, Z. (2016). The Compatibility Student Choice of University Majoring; A Preliminary Studies. GUIDENA: Jurnal Ilmu Pendidikan, Psikologi, Bimbingan Dan Konseling, 6(1), 101-109.

Daharnis, D., \& Ardi, Z. (2017). Optimizing the Counselors' Role in Senior High School and Higher Education.

Daharnis, D., \& Ardi, Z. (2018). The Use of Psychological Tests for Early Childhood. In Proceedings of the International Conference of Early Childhood Education (ICECE 2017). Paris, France: Atlantis Press. https://doi.org/10.2991/icece-17.2018.31

Daharnis, D., Ardi, Z., \& Ifdil, I. (2018). The Improved of Counselor Competencies through Scientific Article Writing Training Using Digital Citation Application. Jurnal Konseling Dan Pendidikan, 6(1), 8.

Dantes, N., Susanta, I. W., \& Suarni, N. K. (2017). The Impact of Cognitive and Emotive Techniques in Rational Emotive Behavioural Therapy Counseling on Aggressive Behavior Tendencies Based on Personality Types among Students of Public Junior High School 4, Denpasar, Bali. The Social Sciences, 12(11), 2123-2127.

de Vries, S. L. A., Hoeve, M., Assink, M., Stams, G. J. J. M., \& Asscher, J. J. (2015). Practitioner review: effective ingredients of prevention programs for youth at risk of persistent juvenile delinquency-recommendations for clinical practice. Journal of Child Psychology and Psychiatry, 56(2), 108-121.

Dehnavi, F., \& Ebrahimi, M. I. (2016). Effect of Assertiveness Skills Training on the Level of Aggression in High School First Grade Female Students in Qorveh City. International Journal of Humanities and Cultural Studies (IJHCS) ISSN 2356-5926, 1421-1434.

Estriyanto, Y., Kersten, S., Pardjono, P., \& Sofyan, H. (2017). The Missing Productive Vocational High School Teacher Competency Standard in the Indonesian Education System. Journal of Technical Education and Training, 9(1).

Grinstein, A., \& Kronrod, A. (2016). Does sparing the rod spoil the child? How praising, scolding, and an assertive tone can encourage desired behaviors. Journal of Marketing Research, $53(3), 433-441$.

Gummadam, P., Pittman, L. D., \& Ioffe, M. (2016). School belonging, ethnic identity, and psychological adjustment among ethnic minority college students. The Journal of Experimental Education, 84(2), 289-306. 
Hawkins, J. D., \& Weis, J. G. (2017). The social development model: An integrated approach to delinquency prevention. In Developmental and Life-course Criminological Theories (pp. 327). Routledge.

Hoffmann, J. P., \& Dufur, M. J. (2018). Family Social Capital, Family Social Bonds, and Juvenile Delinquency. American Behavioral Scientist, 0002764218787020.

Ifdil, I., \& Ardi, Z. (2013). Konseling Online Sebagai Salah Satu Bentuk Pelayanan E-konseling. Jurnal Konseling Dan Pendidikan, 1(1), 15-22.

Jang, H., Kim, E. J., \& Reeve, J. (2016). Why students become more engaged or more disengaged during the semester: A self-determination theory dual-process model. Learning and Instruction, 43, 27-38.

Keliat, B. A., Tololiu, T. A., Daulima, N. H. C., \& Erawati, E. (2015). Effectiveness assertive training of bullying prevention among adolescents in west java Indonesia. International Journal of Nursing, 2(1), 128-134.

Mazur, J. E. (2016). Learning \& behavior. Routledge.

Moffitt, T. E. (2017). Adolescence-limited and life-course-persistent antisocial behavior: A developmental taxonomy. In Biosocial Theories of Crime (pp. 69-96). Routledge.

Organization, W. H. (2016). Global strategy on human resources for health: workforce 2030.

Osgood, D. W., Wilson, J. K., O'malley, P. M., Bachman, J. G., \& Johnston, L. D. (2017). Routine activities and individual deviant behavior. In Crime Opportunity Theories (pp. 49-69). Routledge.

Parray, W. M., \& Kumar, S. (2017). Impact of assertiveness training on the level of assertiveness, self-esteem, stress, psychological well-being and academic achievement of adolescents. Indian Journal of Health and Wellbeing, 8(12), 1476-1480.

Patterson, G. R., DeBaryshe, B. D., \& Ramsey, E. (2017). A developmental perspective on antisocial behavior. In Developmental and Life-course Criminological Theories (pp. 2935). Routledge.

Plantz, M. C., \& Garbarino, J. (2017). Child abuse and juvenile delinquency: What are the links? In Troubled youth, troubled families (pp. 27-40). Routledge.

Puri, A., \& Luqman, N. (2015). Assertiveness as a road to mental well being: case study of an adolescent. International Journal of Multidisciplinary and Current Research, 3, 73-75.

Rani, S., Chandran, S., \& Singal, A. (2016). A Quasi Experimental Study to assess the Effectiveness of Assertiveness Training on Assertive Behaviour and Self Esteem among Adolescent Girls in Selected Government Schools of Panipat, Haryana, 2015. International Journal of Psychiatric Nursing, 2(2), 25-31.

Restu, Y., Yusri, Y., \& Ardi, Z. (2013). Studi Tentang Perilaku Agresif Siswa di Sekolah. Konselor, 2(1).

Schry, A. R., \& White, S. W. (2016). Social anxiety and resistance techniques in risky sexual scenarios: A possible mechanism of increased risk of victimization. Personality and Individual Differences, 88, 242-246. 
Simmons, C., Steinberg, L., Frick, P. J., \& Cauffman, E. (2018). The differential influence of absent and harsh fathers on juvenile delinquency. Journal of Adolescence, 62, 9-17.

Speed, B. C., Goldstein, B. L., \& Goldfried, M. R. (2018). Assertiveness training: A forgotten evidence-based treatment. Clinical Psychology: Science and Practice, 25(1), e12216.

Sue, D., Sue, D. W., Sue, S., \& Sue, D. M. (2015). Understanding abnormal behavior. Cengage Learning.

Sweeney, J. C., Danaher, T. S., \& McColl-Kennedy, J. R. (2015). Customer effort in value cocreation activities: Improving quality of life and behavioral intentions of health care customers. Journal of Service Research, 18(3), 318-335.

Syahniar, S., Ifdil, I., Afdal, A., \& Ardi, Z. (2018). The Responsibility of Counselor and Education in Millennium Era.

Sykes, G. M., \& Matza, D. (2017). Juvenile delinquency and subterranean values. In Cultural Criminology (pp. 3-10). Routledge.

Tandoc, E. C., Ferrucci, P., \& Duffy, M. (2015). Facebook use, envy, and depression among college students: Is facebooking depressing? Computers in Human Behavior, 43, 139-146.

Tennant, J. E., Demaray, M. K., Malecki, C. K., Terry, M. N., Clary, M., \& Elzinga, N. (2015). Students' ratings of teacher support and academic and social-emotional well-being. School Psychology Quarterly, 30(4), 494.

Valverde, M. E., Hernández-Pérez, T., \& Paredes-López, O. (2015). Edible mushrooms: improving human health and promoting quality life. International Journal of Microbiology, 2015.

Western, D. (2018). Conservation for the Twenty-first Century.

Yanti, S., Erlamsyah, E., Zikra, Z., \& Ardi, Z. (2013). Hubungan antara Kecemasan dalam Belajar dengan Motivasi Belajar Siswa. Konselor, 2(1).

Yendi, F. M., Ardi, Z., \& Ifdil, I. (2014). Counseling Services for Women in Marriage Age. Jurnal Konseling Dan Pendidikan, 2(3), 31-36. 